\title{
Serotonin transporter gene polymorphism (5-HTTLPR), environmental conditions, and developing negative emotionality and fear in early childhood
}

Ursula Pauli-Pott · Susann Friedel •

Anke Hinney · Johannes Hebebrand

Published online: 18 July 2009

(C) Springer-Verlag 2009

Erratum to: J Neural Transm (2009) 116:503-512

DOI 10.1007/s00702-008-0171-z

The correct author list is given here:

Ursula Pauli-Pott • Susann Friedel · Anke Hinney . Johannes Hebebrand

The online version of the original article can be found under doi:10.1007/s00702-008-0171-z.

U. Pauli-Pott $(\bowtie)$

Department of Medical Psychology, Faculty of Medicine,

University of Giessen, Friedrichstrasse 36,

35392 Giessen, Germany

e-mail: ursula.pauli-pott@psycho.med.uni-giessen.de

S. Friedel $\cdot$ A. Hinney $\cdot$ J. Hebebrand

Department of Child and Adolescent Psychiatry,

University of Duisburg-Essen, Essen, Germany 